\title{
Meaning of Radicalization
}

\author{
Purwati Purwati $^{1 *}$, Ace Suryadi², Kama Abdul Hakam³ ${ }^{3}$ Cece Rakhmat ${ }^{4}$
}

\author{
${ }^{1,2,3,4}$ General and Character Education, School of Postgraduate Studies, Universitas Pendidikan Indonesia \\ *Corresponding author. Email: purwati_purwati@upi.edu
}

\begin{abstract}
This study aims to build a symbolic agreement about the meaning of radicalization. This objective was determined based on the background of the writing of this article, i.e., the issue of radicalism, which is now widely discussed both on social media and daily talks in the society. Various interpretations of radicalism have created debates in various circles. Furthermore, they have triggered social conflicts spreading to different aspects of life and the division of society into several groups according to their respective interpretations. If people misunderstand radicalism on a moral knowing level, it will affect the form of their moral feeling and moral action in responding to the phenomenon of radicalism in the current era. Therefore, the problems formulated in this article are comprehensively about the meaning of radicalism according to various points of view. There are two benefits to studying this. First, theoretical benefit will enrich scientific knowledge around radicalism. Second, practical benefit is as a scientific resource for academics in assessing phenomena, researching cases, and determining indicators of a person or group exposed to radicalism. This study uses a qualitative approach and library research methods. The data were presented in the form of descriptions and validated using theoretical triangulation. The results of this study show that there was a correlation among the meanings of radicalism obtained based on the different points of view from the researchers examining this issue. This is based on a comprehensive study involving symbolic meaning and synoptic meaning (philosophy, religion, and history).
\end{abstract}

Keywords: radicalism, radicalization, symbolic, synoptic

\section{INTRODUCTION}

Nowadays, there are many cases and news about radicalism. It has been the headline on television, mass media both online and offline, as well as social media. Besides, many people have also been discussing it in the academic world (Abdurrohman \& Syamsiar, 2017). Eventually, radicalism has become a familiar world to people, either by common people or academician.

Such plenty cases and news cause new problem related to the meaning of radicalism. Some people consider radicalism is closely related to violence, terrorism, and intorelant behavior. Some other understand radicalism as a good teaching and it is not against humanity. As the consequence, such different point of view in understanding radicalism become dispute in people's current social interaction. Such term confuses the people who try to understand it (Githens-Mazer, 2012).

Such issue of the way people understand radicalism emerges new issue which is the confusion to determine people who are exposed to radicalism. The confusion makes those who do not support radicalism seems to support the teaching and vice versa. One of the alternative solutions in solving the confusion is the need to determine the indicator for someone who support radicalism. However, before we further determine this indicator, a deep study related to the meaning of radicalism is required. It is because the meaning is related to the intention of a word (Tim Penyusun Kamus Pusat Bahasa, 2008). The study of meaning is the most basic level in understanding radicalism. Therefore, this study is the foundation in building a house. If the form of the foundation is good, it would strengthen the form of the house. It is similar with the study of the meaning of radicalism, if the meaning is clear then it would help someone in determining those indicators so that it could help someone from the wrong way of thinking in the meaning of radicalism.

This issue of interpretation also emerges another new issue that influences individual in determining the correct actions in responding various phenomenon of radicalism surrounding. It is based on the study of analysis about the process of character development start from moral knowing, moral feeling, to moral action (Lickona, 2015b). If someone made a mistake or had a wrong thought in understanding the term radicalism, it would influence the form of his belief towards the true meaning of radicalism. The failure in determining the truth might make someone encounters difficulty in moral action level. Such situation may make them take the wrong action.

Based on the explanation in the previous paragraph, a study on the meaning of radicalism is carried out. The meaning of the term is studied in two meanings; symbolic meaning and synoptic meaning. Both meanings are parts of human essential meanings (Phenix, 1964). On the symbol of meaning, the aspect studied is ordinary language. It discusses 
the conversation on the meaning of radicalism in the research world, mass media and social media. Act and dictionary. On the synoptic meaning of philosophy aspect, the meaning of radical thinking is discussed philosophically in obtaining the knowledge or discovering the truth. On the synoptic meaning of religious aspect, it discusses the perspective of various religions regarding with radicalism from Islam, Christian, Hinduism, Buddhism, and Confucian. On the synoptic meaning of historical aspect, radicalism is studied from the early emergence of the term up to the occurrence of its change.

\section{RESEARCH METHOD}

This research applies qualitative approach. It is chosen to answer research questions that could not be answered by quantitative research (Guest, Namey, \& Mitchell, 2017). The method used was library research. The method was carried out by studying the meaning of radicalism from various sources such as journals, books, or other sources. Library research also has other term such as literature study. The data is presented through description. Once it is described, the data is validated by using theory of triangulation.

\section{RESULT AND DISCUSSION}

\subsection{The Meaning of Radicalism in the Study of Symbolic Meaning}

Ordinary language is one type of symbol in symbolic meaning study (Phenix, 1964). In this research, ordinary language Hakam (in Purwati, 2018) suggested that ordinary language is related with the language that is familiar to people.

In daily life, radicalism is familiar and understood as something related to violence. It could be identified from various conversation in the research world, mass media and dictionary.

\subsubsection{Discussion on Radicalism in the Research World}

Nowadays, people understand radicalism as the teaching supporting the acts of violence or the acts that are against humanity. It could be identified by analyzing various views of the current people on the journal article. There are ten ideas connecting radicalism and violence.

First, Smith, Blackwood, \& Thomas (2019) suggest that radicalization is a process of group socialization about a norm related to violence or not. The socialization mentioned here means introducing the understanding if it is allowed or not to commit violence. Such thing is also followed by foundation in the form of regulation.

Second, Doosje et al. (2016) suggested that radicalization is a process of someone having the will to use violence to someone outside their group. In this definition, it could be seen that radicalism is the teaching that leads to the intolerant behavior or the act not to accept difference in social life. Everyone is demanded to have the same understanding.
If not, then violence is allowed. Besides showing the existence of intolerant behavior, there is also a form of coercion against humanity. Violence is justified if it went along with a certain group and it would not be applied if everyone was on the same page or there had not been any difference. The objective is to create the change in behavior as expected and to realize political objectives. (Doosje et al., 2016).

Third, Porta \& LaFree (2012) define radicalization as a process that leads to political violence. This view connects radicalism to politic. Political violence could be done by individual or group. For instance, rebellion against the state, the massacre of a certain ethnic by a state or war against other nation for a certain political objective.

Fourth, Borum (2012b) suggested radicalization as a process of developing ideology and belief in extreme, violent or in terror. The ideology here means ideas, notions, or view of life creating regulation that allows violence in reaching a certain objective. The idea is believed to be the right thing and such belief becomes the power in determining the act of violence.

Fifth, Neumann (2013) suggested that radicalization in the basic level is interpreted as the process of change in someone which eventually leads him/her to be an extremist. On this view, radicalization meant is still in the way of thinking and believing the truth of an understanding. The form of this thinking and belief would create action. Extreme actions are actions beyond the limit, out of the box, either beyond the limit of law or religion.

Sixth, Kruglanski et al. (2014) explains that radicalization is a process of encouraging some to take an action that is not appropriate with social norm such as killing civilians. This view shows that radicalism is against the social norm. It means it does not fit with the common habit, as well as the applied law and regulation or it does not fit with the life guidelines held by a certain group of people.

Seventh, Bolsi and Malthaner (in Porta, 2018) argued that radicalization is the process of improving and preparing actions which previously was anti-violence action to become an action of violence. Lickona (2015) in his book argued that the quality of thought could influence action. If the thought was related to this study, then the meaning of Bolsi and Maltahmer's view on how to change someone's mindset might influence their actions. If at the beginning, someone's mind had ideas against violence, and if it was influence, then it would change into supporting violence.

Eighth, Sedgwick (2010) suggested that radicalization is a term to describe the condition before the emergence of riot such as bombing. This view is still directed to the violence in interpreting radicalism. The condition mentioned is preparing individuals to have the courage to commit violence. The preparation is started by emulating the way of thinking and belief in justifying this action. 
Ninth, Horgan \& Braddock (2010) explain that radicalization is a psychological and social process related to extreme political and religious ideology. Psychological process is related to the individual as the mental target, while social process is a group of individuals to perform massive actions.

Tenth, Borum (2012a) suggested that radicalization is a process started from the emergence of complaint over an issue which is spread so that it boost the emergence of a radical ideology. This view interprets such term on the background aspect of the emergence of this radicalism. The emergence of social issue which is getting more and more complicated and remains unsolved might encourage someone or a group of people to think radically and perform radical actions.

\subsubsection{Discussion on Radicalism in Mass Media and Social Media}

Mass media has become one of the factors that makes the term radicalism familiar to the current generation. Mass media could be television, radio, or newspaper. Besides, the other factor could also be contents wide-spread in the entire social media such as Youtube, Instagram, Facebok, WhatsaApp, Tiktok, etc.

Mass media and social media are frequently broadcasting various cases of radicalism in the life of the people. It becomes something usual and might build symbolic agreement indirectly that the meaning of radicalism currently is related to the understanding supporting the violence to reach a certain objective. It could be observed by considering various of news. On media Kompas, there had been a news discussing that radicalism is understood as the teaching about how to create change using violence. Either in the form of physical or symbol (Ghufron, 2017). On one of the news in Liputan6 media, radicalism is a teaching related to terrorism or extremism in performing the movement in order to create massive social change (Sendari, 2021). On one of the news from Berita Satu, Radicalism is generally could have both positive and negative, while in the new interpretation, the effort involving violence in changing the system of the state (Mahfud MD, in Wardi, 2019). On one of the news from Antara News, radical in positive meaning related to the revolutionary way of thinking that might change bad habits into the good ones (Anwar, in Prihantoro, 2019). Besides, on one of the news from Suara, it is explained that radicalism in positive meaning means that everything should be traced to the foundation, root or authenticity, and becomes positive should interpret it contextually. (Aditya, 2021).

\subsubsection{The Discussion on Radicalism in Law and Big Dictionary}

According to the Tim Penyusun Kamus Pusat Bahasa (2008), radical is the knowledge about political change through radical way, thorough change, while radicalism itself is the teaching supporting radical way in politic.
In Undang-Undang Republik Indonesia Nomor 5 Tahun 2018, there has not been found any precise definition about the term radical and radicalism. There is only the definition of deradicalization and radical organization. In UndangUndang Republik Indonesia Nomor 5 Tahun 2018 Pasal 43D, deradicalization is considered as efforts to eliminate and replace the understanding about terrorism and radicalism, while point $I$ in part General, it is explained that radical organization and tend to have terrorism actions is considered as evil, massive, and endanger national or international peace. Should both these definitions are analyzed, then it could be understood that radicalism as the teaching that supports violence as its existence have a danger potential for human life.

\subsection{The Meaning of Radicalism in Synoptic Study of Meaning}

\subsubsection{The Meaning of Radicalism in Philosophy Perspective}

Plato (in Wahana, 2016) suggested that philosophy discusses about the process of investigation towards causality principle of something. The investigation is carried out for the existence of hesitation towards the object being thought. This investigation aims to obtain the truth by using thought and keep questioning until satisfactory answers are found.

Thinking radically is a characteristic of someone philosophizing (Sumarna, 2020). It is connected to the process of investigation, then someone needs to be radical in thinking to remove the feeling of hesitation over the truth being searched or believed. Radical thinking means thinking deeply to the roots. It is derived from its word of origin, radix or roots. Someone who thinks radically could be seen as the roots of a tree. That roots branched down and to the side too. If the roots get wider, then the tree would be more firmly stand. Someone who think deeply, thoroughly to the very basic then s/he would found the undoubted truth. The truth is strong to be believed since it has all answers to the doubt and solve the real issues. The result of such radical thinking is to discover new knowledge or to strengthen the existing knowledge.

\subsubsection{The Meaning of Radicalism in History Perspective}

The term radical was first introduced by Charles James Fox in 1797 in England (Sunarto, 2017). Such radical movement was carried out in order to realize the parliamentary reformation. According to Tim Penyusun Kamus Pusat Bahasa (2008), reformation means drastic change in politics, religion, and social. Reformation has a good objective since it is considered as an effort for an improvement (Azizy, 2007). If reformation is related to the parliament or bureaucracy, then it means that reformation is an effort to improve the way of thinking, the will and the effort to close the opportunity to perform moral deviation. If such definition of moral is related to the history of the emergence of the term radical, then it could be said that at the beginning, the term radical has positive meaning since it 
carries constructive meaning in realizing change for a betterment.

Besides, other evidence that the term radical or radicalism had a positive meaning was that the explanation of such term in the book entitled Di Bawah Bendera Revolusi Vol. I by Sukarno, the first president of Indonesia. If it is analyzed, the meaning of radical or radicalism in that book, Sukarno defined this term in the perspective of philosophy. The reason is that in that book, it was explained that radix or the root is the word of origin of radicalism so that the word has the meaning that fighting should be performed thoroughly to the grass-root including the aspect of spirit, mind quality and action (Soekarno, 2016). Radicalism here has a positive meaning since it aims to fight the colonialist torturing Indonesian people.

As the age changes, the term radical shifted its meaning and it closes to the ideology and the group expecting the change through revolution in the scope of social and politics in a hard way (Administrator, 2021). The existence of violence makes the term radical or radicalism to have negative meaning. This negative meaning is stronger in the majority of the current generation with various of cases published in mass media. Indirectly, such situation encourages the formation of majority agreement that radical or radicalism has negative meaning since it is closely related to violence.

\subsubsection{Radicalism in the Perspective of Religions}

This study discusses the phenomenon of violence through the perspective of various religions. The reason to relate this study to religion is that because human is God's creation and the truth of religions is absolute.

The first perspective, according to Islam. The term jihad is closely attached to this religion. That term is frequently mistaken since it is related to radicalism and violence. It causes negative label towards Islam. As the consequence, Islam is seen as the religion that supports violence, even though the fact is quite the opposite. Rodin (2016) suggested that jihad is not about warfare but more about human welfare. Based on his analysis in a journal, Rodin (2016) explained that in the holly book of Islam about jihad and war, there have not been found any verse allowing violence in solving problems. The second Perspective, according to Christian. Zega (2020) suggested that in Christian, God does not fond of violence and the evidence of faith is proven through piety life on daily activities. The third perspective, according to Hinduism. Vedanti (2017) suggested that in the religion of Hindu, there is a teaching about harmony with God, with people, and with nature. The fourth perspective, according to Buddha. Kamaluddin (2019) suggested that in the view of Buddha, those who have the religious mental maturity are those who have character of tolerance. It means that, one should be able to accept and appreciate various difference. Therefore, it shows those religions do not allow violence since they care about life harmony despite the difference. The fifth perspective, according to Confucius. Yasin \& Saputra
(2021) suggested that Confucius teaches the importance of having love despite of difference since it is part of the richness of God's creation.

Such varied perspectives show that Islam, Christian, Hinduism, Buddha, and Confucius are the religions who do not support violence since considering humanity, creating peaceful lives, and appreciate the existence of different in daily life. Should this explanation is related to radicalism in negative meaning (the new meaning understood by the common people nowadays), hence, it could be concluded that those religions do not support radicalism.

\section{CONCLUSION}

There are three conclusions about the meaning of radicalism. The first conclusion, according to symbolic meaning (ordinary language). Radicalism has negative meaning (against the humanity), so that the meaning is that it is a teaching supporting violence in order to reach an objective. It is based on the symbolic agreement formed indirectly by the current generation discussing it in daily life, both in the research world (in various article of international journal) or in mass media or netizen's discussion in social media. The second conclusion, according to the synoptic meaning, philosophical aspect has positive meaning since it is related to the process of deep and comprehensive thinking to find the truth. From historical aspect, the meaning of radicalism in the past had positive meaning since the meaning given was in the context of philosophical thinking and as the knowledge about the action against the cruelty of colonialists. Religious aspect, all religions (Islam, Christian, Hindu, Buddha, and Confucius) upholding humanity values. Therefore, if the radicalism meaning was taken in the context of new meaning (negative meaning of radicalism), then each religion does not support radicalism or the teaching allowing violence in reaching the objective. The third conclusion, the real meaning of radicalism that could be understood is that if it was started by determining in what context the discussion was, either in terms of time (the past or present) or the change of meaning (original meaning and new meanings)

\section{REFERENCES}

Abdurrohman, \& Syamsiar, H. (2017). Pembelajaran Pendidikan Agama Islam (PAI) Model Keberagamaan Inklusif untuk Mencegah Radikalisme Beragama Di Kalangan Siswa SMA. FENOMENA: Jurnal Penelitian, 9(1), 105-122.

Aditya, R. (2021). Apa Itu Radikal yang Belakangan Menggegerkan Politik Indonesia? Retrieved from https://www.suara.com/news/2021/02/16/064025/apa -itu-radikal-yang-belakangan-menggegerkan-politikindonesia?page $=$ all

Administrator. (2021). Istilah Radikal Harus Diganti? Retrieved June 20, 2021, from Indonesia.Go.Id: Portal Informasi Indonesia website: 
https://indonesia.go.id/ragam/budaya/sosial/istilahradikal-harus-diganti.

Azizy, A. Q. A. (2007). Change Management dalam Reformasi Birokrasi. Jakarta: PT Gramedia Pustaka Utama.

Borum, R. (2012a). Radicalization into Violent Extremism II: A Review of Conceptual Models and Empirical Research. Journal of Strategic Security, 4(4), 37-62. https://doi.org/http://dx.doi.org/10.5038/19440472.4.4.2.

Borum, R. (2012b). Rethinking Radicalization. Journal of Strategic Security, 4(4), 1-6. Retrieved from https://scholarcommons.usf.edu/jss/vol4/iss4/1.

Doosje, B., Moghaddam, F. M., Kruglanski, A. W., Wolf, A. de, Mann, L., \& Feddes, A. R. (2016). Terrorism, Radicalization and De-radicalization. Current Opinion in Psychology, 11, 79-84. https://doi.org/https://doi.org/10.1016/j.copsyc.2016. 06.008 .

Ghufron, F. (2017). Radikalisme dan Politik Identitas. Kompas. $\quad$ Retrieved from https://nasional.kompas.com/read/2017/05/05/191708 71/radikalisme.dan.politik.identitas?page=all.

Githens-Mazer, J. (2012). The rhetoric and reality: radicalization and political discourse. International Political Science Review, 33(5), 556-567. https://doi.org/https://doi.org/10.1177\%2F019251211 2454416.

Guest, G., Namey, E. E., \& Mitchell, M. L. (2017). Collecting Qualitative Data: A Field Manual for Applied Research.

https://doi.org/https://dx.doi.org/10.4135/978150637 4680 .

Horgan, J., \& Braddock, K. (2010). Rehabilitating the Terrorists?: Challenges in Assessing the Effectiveness of De-radicalization Programs. Terrorism and Political Violence, 22, 267-291. https://doi.org/10.1080/09546551003594748.

Kamaluddin. (2019). Memahami Pesan Ajaran Agama secara Dewasa Salah Satu Syarat untuk Mewujudkan Toleransi. Studia Sosia Religia, 2(1), 27-38.

Kruglanski, A. W., Gelfand, M. J., Bélanger, J. J., Sheveland, A., Hetiarachchi, M., \& Gunaratna, R. (2014). The Psychology of Radicalization and Deradicalization: How Significance Quest Impacts Violent Extremism. Advances in Political Psychology, 35(1), 69-93. https://doi.org/10.1111/pops.12163.

Lickona, T. (2015a). Character Matters Persoalan Karakter Bagaimana Membantu ANka Mengembangkan Penilaian yang Baik, Integritas. dan Kebajikan Penting Lainnya. Jakarta: Bumi Aksara.
Lickona, T. (2015b). Educating for Character Mendidik untuk Membentuk Karakter Bagaimana Sekolah Dapat Mengajarkan Sikap Hormat dan Tanggung Jawab. Jakarta: Bumi Aksara.

Neumann, P. R. (2013). The Trouble with Radicalization. International Affairs, 89(4), 873-893. Retrieved from https://www.jstor.org/stable/23479398.

Phenix, P. H. (1964). Realms of Meaning. New York: McGraw Hill Book Company.

Porta, D. della. (2018). Radicalization: A Relational Perspective. Annual Reviews, 21, 461-474. https://doi.org/https://doi.org/10.1146/annurevpolisci-042716-102314.

Porta, D. Della, \& LaFree, G. (2012). Guest Editorial: Processes of Radicalization and De-Radicalization. International Journal of Conflict and Violence, 6(1), 4-10. https://doi.org/https://doi.org/10.4119/ijcv2926.

Prihantoro, A. (2019, November 5). MUI: Perlu Definisi Ulang Istilah Radikalisme. Antara News. Retrieved from

https://www.antaranews.com/berita/1148008/muiperlu-definisi-ulang-istilah-radikalisme.

Purwati. (2018). Analisis Interaksi Simbolik di Sekolah Dasar dalam Membangun Karakter Siswa. Universitas Pendidikan Indonesia.

Rodin, D. (2016). Islam dan Radikalisme: "Kekerasan", Telaah atas Ayat-ayat Al-Qur'an, Dalam. ADDIN, 10(1), 29-60.

Sedgwick, M. (2010). The Concept of Radicalization as a Source of Confusion. Terrorism and Political Violence, 22(4), 479-494. https://doi.org/https://doi.org/10.1080/09546553.201 0.491009

Sendari, A. A. (2021). Radikalisme adalah Paham Perubahan Ekstrem, Kenali Ciri-Cirinya. Liputan6. Retrieved from https://hot.liputan6.com/read/4456602/radikalismeadalah-paham-perubahan-ekstrem-kenali-ciricirinya\#: :text=Radikalisme adalah konsep dengan arti,dengan konsep ekstremisme dan terorisme.

Smith, L. G. E., Blackwood, L., \& Thomas, E. F. (2019). The Need to Refocus on the Group as the Site of Radicalization. Association for Psychological Science, $1-26$.

https://doi.org/https://doi.org/10.1177\%2F174569161 9885870

Soekarno. (2016). Dibawah Bendera Revolusi (Jilid I). Jakarta.

Sumarna, C. (2020). Filsafat Ilmu: Mencari Makna Tanpa Kata dan Mentasbihkan Tuhan dalam Nalar. Bandung: PT Remaja Rosda Karya. 
Sunarto, A. (2017). Dampak Media Sosial terhadap Paham Radikalisme. NUANSA: Jurnal Penelitian Ilmu Sosial Dan Keagamaan, X(2), 126-132.

Tim Penyusun Kamus Pusat Bahasa. (2008). Kamus Bahasa Indonesia. Jakarta: Pusat Bahasa Departemen Pendidikan Nasional.

Undang-Undang Republik Indonesia Nomor 5 Tahun 2018 tentang Perubahan atas Undang-Undang Nomor I5 Tahun 2003 tentang Penetapan Peraturan Pemerintah Pengganti Undang-Undang Nomor L Tahun 2002 tentang Pemberantasan Tindak Pidana Terorisme Menjadi Undang-Und. , (2018).

Vedanti, K. A. (2017). Peran Penyuluh Agama Hindu dalam Pembentukan Karakter Anti Radikalisme. Dharma Duta: Jurnal Penerangan Agama Hindu, 15(2), 5973.

Wahana, P. (2016). Filsafat Ilmu Pengetahuan. Yogyakarta: Pustaka Diamond.

Wardi, R. (2019, November 12). Ini Tiga Definisi Radikalisme Menurut Menko Polhukam. Berita Satu. Retrieved from https://www.beritasatu.com/nasional/584889/ini-tigadefinisi-radikalisme-menurut-menko-polhukam

Yasin, T. H., \& Saputra, H. (2021). Toleransi Beragama Perspektif Islam dan Kong $\mathrm{Hu} \mathrm{Cu}$. Abrahamic Religions: Jurnal Studi Agama-Agama, 1(1), 41-54.

Zega, Y. K. (2020). Radikalisme Agama dalam Perspektif Alkitab dan Implikasinya Bagi Pendidikan Agama Kristen. Jurnal Shanan, 4(1), 1-20. 